\title{
Coral diversity on artificial reef from coconut shells in northern Bali, Indonesia
}

\author{
EGHBERT ELVAN AMPOU ${ }^{1, \bullet}$, GEDE IWAN SETIABUDI ${ }^{2}$, NURYANI WIDAGTI ${ }^{1}$, \\ I NYOMAN DODIK PRASETIA ${ }^{2}$ \\ ${ }^{1}$ Institute for Marine Research and Observation, Ministry of Marine Affairs and Fisheries. Jl. Baru Perancak, Jembrana 82251, Bali, Indonesia. \\ Tel.: +62-365-44266, Fax.: +62-365-44278, `email: eghbert.ampou@kkp.go.id \\ ${ }^{2}$ Program of Aquaculture, Faculty of Mathematics and Natural Sciences, Universitas Pendidikan Ganesha. J1. Udayana No. 11, Singaraja, Buleleng \\ 81116, Bali, Indonesia
}

Manuscript received: 29 May 2020. Revision accepted: 27 August 2020.

\begin{abstract}
Ampou EE, Setiabudi GI, Widagti N, Prasetia IND. 2020. Coral diversity on artificial reef from coconut shells in northern Bali, Indonesia. Biodiversitas 21: 4331-4338. Coral reef ecosystems are very vulnerable to damage and require treatment such as artificial reefs. Artificial reef from natural product bioreeftek is very easy to apply and can be found in many tropical coastal areas namely coconut shells with natural coral recruitment. The purpose of this study was to calculate the percentages of coral cover, ratio and clustering of corals. At the two research sites in northern Bali, on the Pemuteran-Napoleon Reef at reef slope, depth of 5-6 m was found 13 species of live coral from 9 bioreeftek, deployed period 2009-2010: Porites sp. 32\%, Pocillopora damicornis 13\%, Seriatopora sp. 10\%, Acropora palifera, Acropora sp., Goniastrea sp., Favia sp., Pachyseris sp. $=6 \%$; Montipora sp.-Echinopora sp.-Favites sp.-Fungia fungites and Leptoseris sp. $=3 \%$. At the Lovina-Adirama Temple at reef flat, depth of $6 \mathrm{~m}$ comprised by 14 species from 14 bioreeftek, deployed period 2014: Acropora palifera 24\%, Pocillopora damicornis 21\%, Porites sp. 7\%, Montipora sp. 4\%-Acropora sp-Pavona sp. $=3 \%$, Platygyra sp. $2 \%$, Acropora humilis-Millepora $=1 \%$. Cluster Analysis showed that all corals at the two sites are correlated in percent cover, characteristics, influences and occurrences. Artificial reefs with natural materials such as coconut shells may be used to address the degradation of coral reef ecosystems. The added value of bioreeftek is insertion method of coral.
\end{abstract}

Keywords: Artificial reef, coconut shells, coral, Indonesia, Lovina, Pemuteran

\section{INTRODUCTION}

Indonesia has vast marine waters encompassing $6.400 .000 \mathrm{~km}^{2}$ bordering a coastline of $108.000 \mathrm{~km}$, and approximately 17504 islands (Geospatial Information Agency 2018). Indonesia has the highest category in the world in terms of coral reef biodiversity, which is estimated at $50.200 \mathrm{~km}^{2}$, although up to now it needs to be revised. Indonesia has various types of reefs including barrier reefs, fringing reefs and atolls (Tomascik et al. 1997). In addition to its high biodiversity, coral reefs in Indonesia also have a very high level of ecological complexity and are included in the center of the world's coral triangle or better known as the Coral Triangle Initiative (CTI) which includes Indonesia, Malaysia, Philippines, Timor Leste, Papua New Guinea and Solomon Islands. More than 500 coral species are spread out of a total of $70 \%$ in the Indo-Pacific (Veron et al. 2009; Foale et al. 2013; Asaad et al. 2018). Bali has a variety of coral reefs, with a total of 406 reef-forming coral species (hermatypic) (Turak and DeVantier 2012). This area also has a high level of reef fish associations and which needs to be managed in a sustainable way (Allen and Steene 1994; Nañola et al. 2011; Cruz-Trinidad et al 2014), and globally as a supplier of tropical marine biodiversity (Turak and DeVantier 2003; Putra et al. 2018).

Coral reefs ecosystems are very vulnerable to damage. Some factors that can threaten the existence of this ecosystem are sedimentation, pollution from industrial and household waste, fisheries activities that are not environmentally friendly (using explosives and poisons), tourism activities, and also climate change in natural factors such as increased sea surface temperatures which can cause bleaching coral if it occurs for a long time period (Hoegh-Guldberg 1999; Grimsditch and Salm 2006; Tito et al. 2019), even some of them experienced coral severe by bleaching and followed with disease (Douglas 2003; Raymundo et al. 2008; Plass-Johnson et al. 2015; Ampou et al. 2020).

The one approach in overcoming the degradation of coral reef ecosystems is to use artificial reef methods (Goreau 2009). Implementation of artificial reefs in Bali has been applied out such as several reef ball units (Fox et al. 2005), Biorock in Pemuteran which is also supported by the local community (Arifin et al. 2017; Trialfhianty and Suadi 2017), several Hexadome units in Buleleng (Yunaldi et al. 2011), artificial reef spider are so-called MARRS (Mars Assisted Reef Restoration System) at Nusa Dua (Ampou et al. 2019), and bioreeftek (Andayani and Ampou 2018).

In this study, we focus on artificial reefs by utilizing natural materials that were relatively not widely used. A large number of coconut trees growing in the coastal areas of Indonesia, in this case, coconut shells, which will become a medium to recruit new coral individuals naturally is an alternative in supporting coral reef rehabilitation programs. This technology is called bioreeftek. This 
artificial reef means green and simple technology that utilizes natural product of coconut shell as a media for attaching coral planula larvae into new individual colonies or reefs (Ampou and Widagti 2018)

The objective of this study was analyze the percentages of coral cover recruitment, composition, and clustering of corals on artificial bioreeftek substrata on hard corals (Scleractinia) in Pemuteran and Lovina, northern Bali.

\section{MATERIALS AND METHODS}

\section{Study location}

Survey activities were carried out in March and September 2018 in northern Bali at two research sites Pemuteran and Lovina, northern Bali, Bali Province, Indonesia (Figure 1). Bioreeftek (Figure 2) at Pemuteran, dive site Napoleon Reef (NR) ( $8^{\circ} 07^{\prime} 55.5^{\prime \prime} S, 114^{\circ} 40^{\prime} 28.0^{\prime \prime}$ $\mathrm{E})$, the number of bioreeftek units monitored $=9$ units on the reef slope area, depth 5-6m, substrate: rock-rubble. Bioreeftek at Lovina dive site Adirama Temple (AT) ( $\left.8^{\circ} 09^{\prime} 52.9^{\prime \prime} \mathrm{S}, 115^{\circ} 00^{\prime} 45.8^{\prime \prime} \mathrm{E}\right)$. The number of bioreeftek units monitored $=14$ units on the reef flat; depth $6 \mathrm{~m}$ with substrate of fine sand.

\section{Data collection}

Sampling procedures are using SCUBA (SelfContained Underwater Breathing Apparatus) equipment, underwater camera, diving slate, and boat. Field data collection has done by using an underwater camera and visual census (English et al. 1997; Bianchi et al. 2004; Ampou 2016). Every single individual coral that was seen recruited on the bioreeftek was shot with underwater camera: Photo transect habitat (Andréfouët, 2008; Scopélitis et al. 2011; Ampou et al. 2018; Putra et al. 2018).

\section{Data analysis}

Data were collected then analysis by using the following formula:

To calculate Percentage of each coral individual on bioreeftek using the formula (Bluman 2012):

$$
\mathrm{f} / \mathrm{n} * 100 \%
$$

Where: f: frequency of corals; $n$ : total coral identified

For the calculation of the coral recruitment ratio in the bioreeftek in AT and NR using the formula adaptation from Larson and Farber (2012):

$$
\mathrm{CR}=\frac{\mathrm{C} b \mathrm{P}}{\mathrm{C} b \mathrm{~L}} \times 100
$$

Where: CR: Coral Ratio; CbP: Number of coral bioreeftek Pemuteran; $\mathrm{C} b \mathrm{~L}$ : Number of coral bioreeftek Lovina.
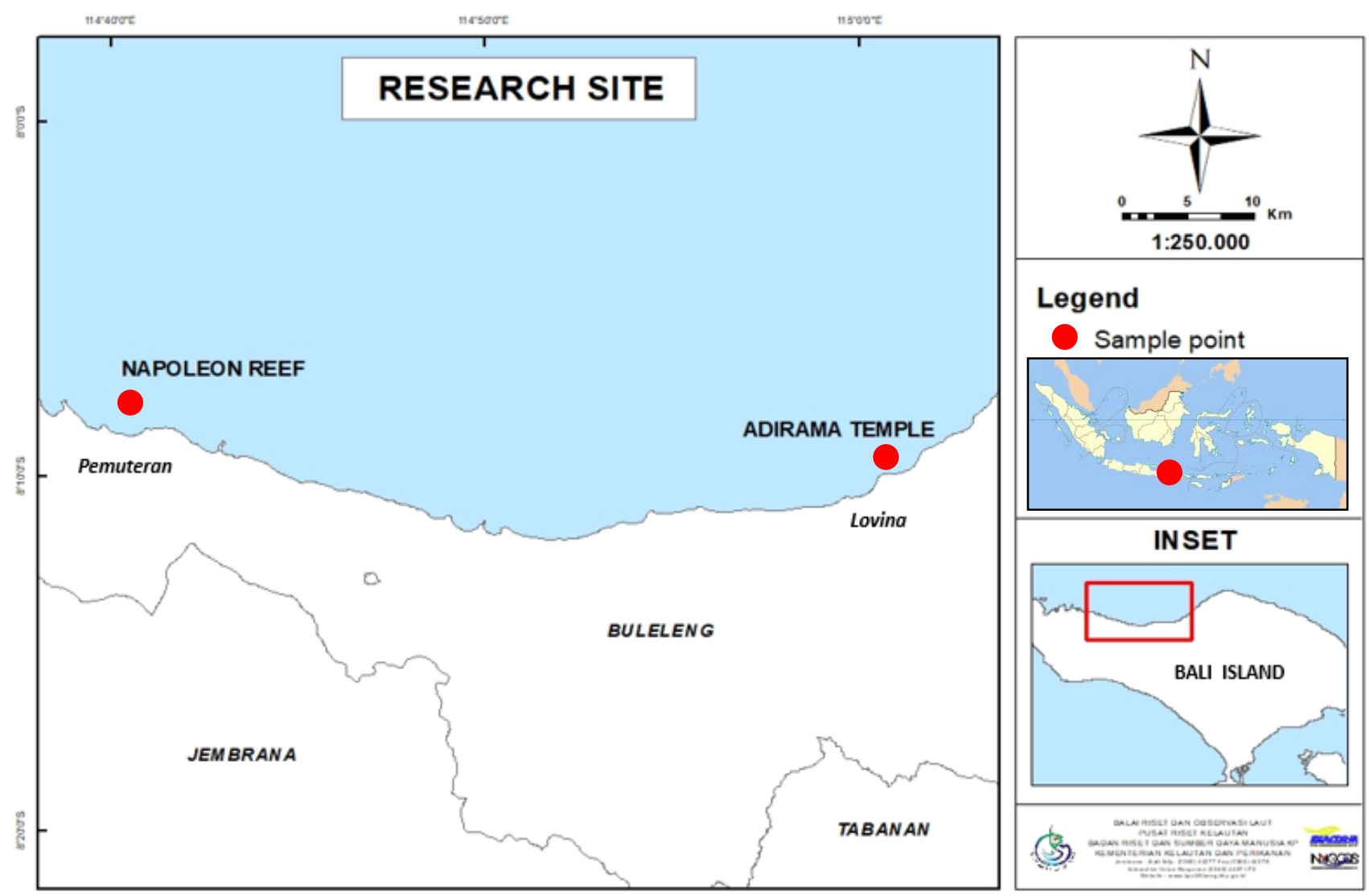

Figure 1. Study site in northern Bali, Indonesia, i.e. Napoleon Reef of Pemuteran and Adarima Temple of Lovina 


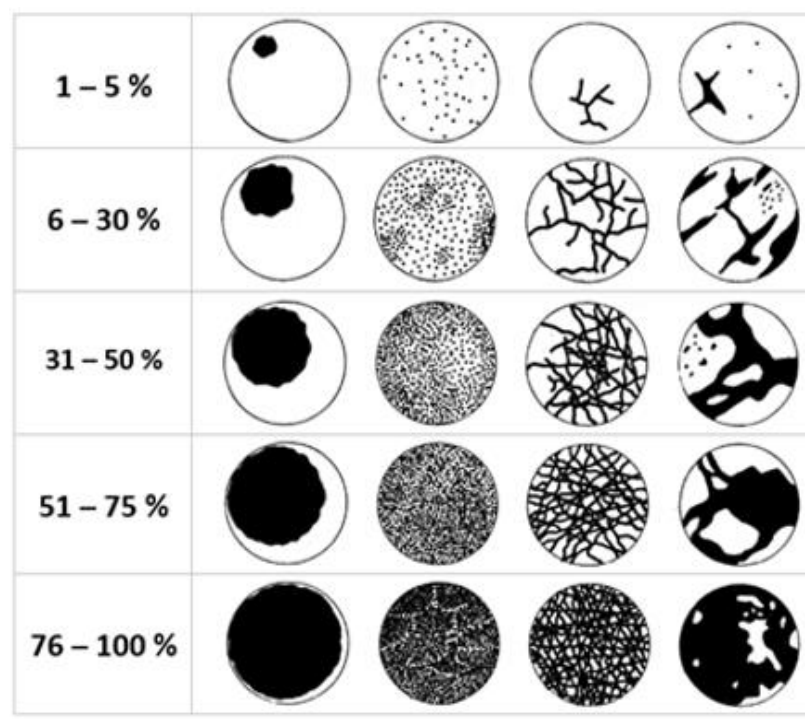

Figure 2. Illustrate some different amounts and types of coral cover (Dahl 1981) is the visual tool used to assess the \% of coral cover on bioreeftek

To identify dense and well-separated and to defined as the ratio between the minimal inter-cluster distance to maximal intra-cluster coral on bioreeftek by using Dunn index (1974); Saha and Bandyopadhyay (2012). For each cluster partition can be calculated by the following formula:

$$
D=\frac{\min _{1 \leq i<j<n} d(i, j)}{\max _{1 \leq k \leq n} d^{\prime}(k)},
$$

Where: $d(i, j)$ : represents the distance between clusters $i$ and $j$, and $d^{\prime}(k)$ : measures the intra-cluster distance of cluster $k$.

The inter-cluster distance $d(i, j)$ between two clusters may be any number of distance measures, such as the distance between the centroids of the clusters. Similarly, the intra-cluster distance $d^{\prime}(k)$ may be measured in a variety of ways, such as the maximal distance between any pair of elements in cluster $k$, in this case, the type of coral among NR and AT.

\section{Natural product artificial reef (bioreeftek)}

This invention relates to a structure for the natural recruitment of coral, especially the structures for the used coconut shells. The structure has a concrete plate on which is mounted vertically a number of aluminum pipes that have a rectangular cross-section with a certain distance to arrange on each of the aluminum pipes a number of half coconut shell containing a mortar that has a translucent hole in the middle. So that the coconut shell half containing the mortar cannot be separated from the aluminum pipe, the aluminum pipe is bound near the top surface of the vertical arrangement of the coconut shell half containing the mortar with a binder. The structure can be combined with other similar structures through hooks available on the concrete slabs of each of these structures. The structure can be

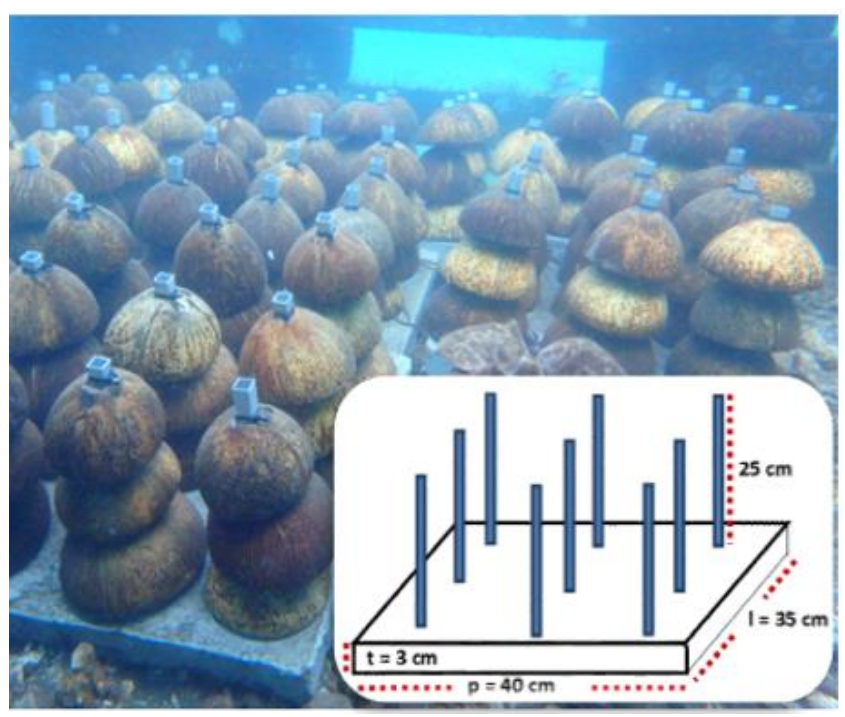

Figure 3. The structure of bioreeftek (submerged)

placed on a seabed permanently or moved to another seabed after corals grow on the structure and can be adjusted depending on diameter of the coconut shells (Ampou 2012) (Figure 3) and can be applied in large quantities (Ferse et al. 2013).

\section{RESULTS AND DISCUSSION}

\section{Results}

The characteristics of the research sites, especially in the coastal waters of Pemuteran, NR and Lovina, AT are the reef flats, reef slopes and patch reef. Bioreeftek at NR was deployed in the period 2009-2010, while in AT was deployed in 2014. All results are described as follows:

The percentage of coral on bioreeftek at Pemuteran-NR depth 5-6m on the reef slope found 13 species of live coral from 9 bioreeftek dominated by massive coral Porites sp. = $32 \%$, followed by coral species Pocillopora damicornis $=$ $13 \%$, Seriatopora sp. $=10 \%$, while Acropora palifera, Acropora sp., Goniastrea sp., Favia sp. and Pachyseris sp. have the same percentage value $=6 \%$, and the lowest identified are Montipora sp., Echinopora sp., Favites sp., Fungia fungites and Leptoseris sp. with the same value also $=3 \%$. (Figure 4 ). In contrast to Lovina-AT, depth of $6 \mathrm{~m}$ on the reef flat was found 14 coral species from 14 bioreeftek which is found as a dominant is Acropora palifera $=24 \%$, then also found the same type of coral in Pemuteran with a different percentage Pocillopora damicornis $=21 \%$, then Porites sp. $=7 \%$, Montipora $\mathrm{sp} .=4 \%$, Acropora $\mathrm{sp}$. and Pavona sp. $=3 \%$, Platygyra sp. $=2 \%$, Acropora humilis and Millepora $=1 \%$ as undominant (Figure 4).

Otherwise, the Coral recruitment ratio (CR) on the bioreeftek in NR and AT shows that the most diversity is in $\mathrm{NR}$, whereas in AT the distribution of coral diversity is relatively lower, is this because there are 13 coral types at NR, and 9 coral types at AR (Figure 5). 
Based on cluster analysis value illustrate that: Acropora palifera and Porites sp. were dominant species-Acropora sp. (in between) and occurred in two sites; Pavona sp.Platygyra sp. (influence-only occurred at Lovina-Porites sp. (massive-influence); Acropora humilis-Millepora sp. (same value-only occurred at Lovina)-Porites sp. (massiveinfluence); Pocillopora damicornis-Porites sp. (dominantoccurred in both sites)-Seriatopora sp. (in betweenoccurred in bioreeftek Pemuteran); Goniastrea sp.-Favia sp. (same value-massive-occurred only in bioreeftek Pemutera)-Porites sp. (massive-influence); Pachyceris sp. (occurred in bioreeftek Pemuteran)-Montipora sp. (same shape-between-occurred both sites)-Porites sp. (massiveinfluence; Fungia fungites-Leptoseris sp. (same shapeoccurred only in bioreeftek Pemuteran); Echinopora sp. and Favites sp. (invisible) which is undominant species on Bioreeftek (Figure 6).

\section{Discussion}

All the type of corals that settles on bioreeftek it's natural recruitment except $\mathrm{C}$ and $\mathrm{D}$ particularly species Acropora palifera (e.g. 5,7), one of the adjacent natural coral species on that location. A coral that is separated from natural habitat and inserted between the sidelines of the bioreeftek by local diver (Figure 7), which means propagation techniques can be implemented (Barton et al. 2017) also on bioreeftek. Artificial reef also really need to be developed for larger scale coral reef rehabilitation programs, more specifically in marine conservation area such as CTI (Williams et al. 2019).

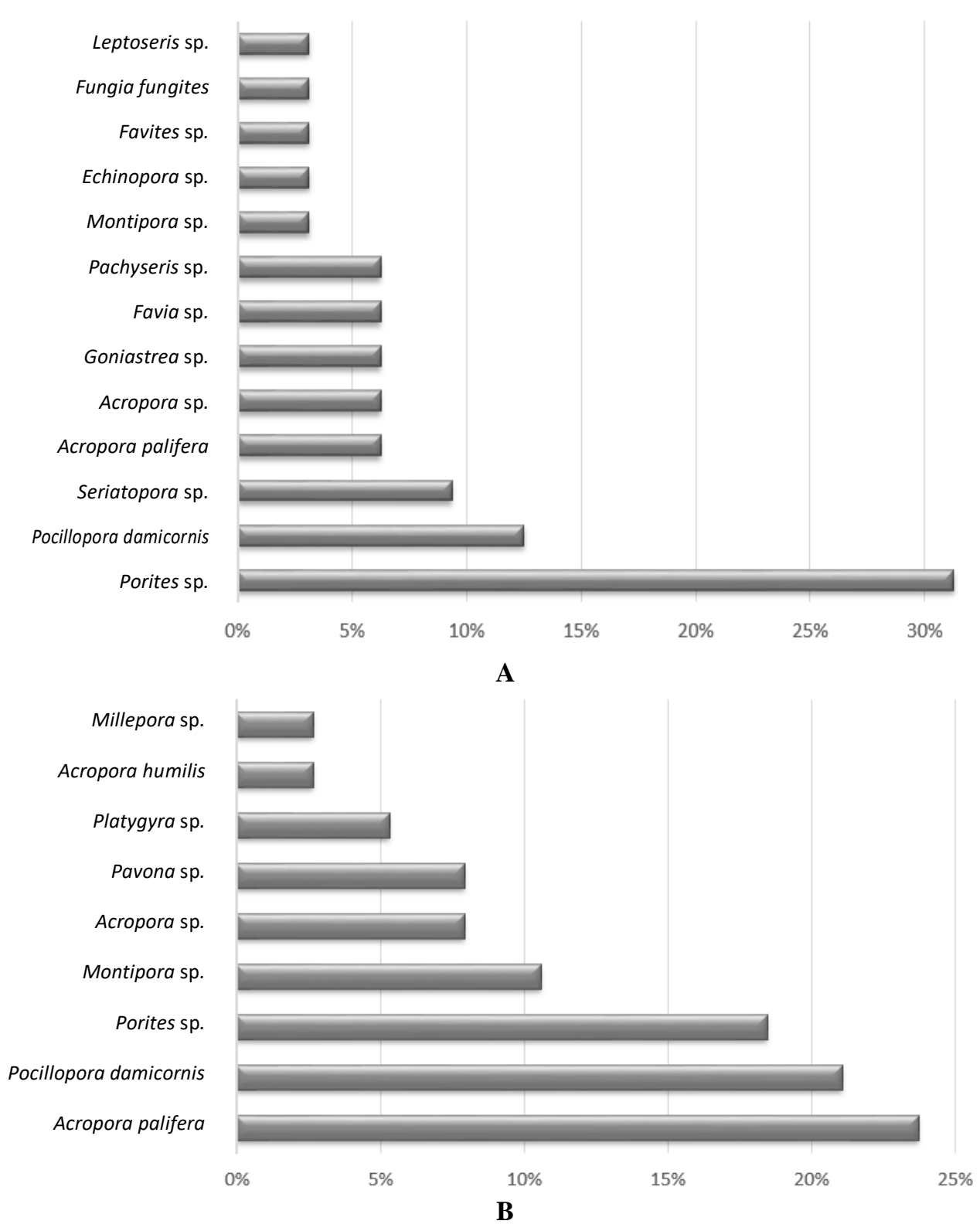

Figure 4. The diversity of coral on bioreeftek in northern Bali, Indonesia: A. Napoleon Reef of Pemuteran, B. Adarima Temple of Lovina 
Recruitment of coral larvae grows well on bioreeftek at reef slopes (Figures 7.A, 7.B). Some structures show that there is little occupation by microalgae, turf algae, crustose coralline algae (CCA), and ascidian. These conditions may cause competition of other biota occupied the space and then larval settlement becomes low. Gomez-Lemos et al. (2018) stated that CCA and some microbes have a role in the success of coral larvae recruitment. Some of these studies may be a subject of deeper discussion, to see the extent to which spatial competition and natural associations affect the success rate of recruitment. Given that the natural product in bioreeftek has the possibility to be overgrown by various types of organisms (Burt et al. 2009). These facts can be recommendations for restoration efforts that require fast time.

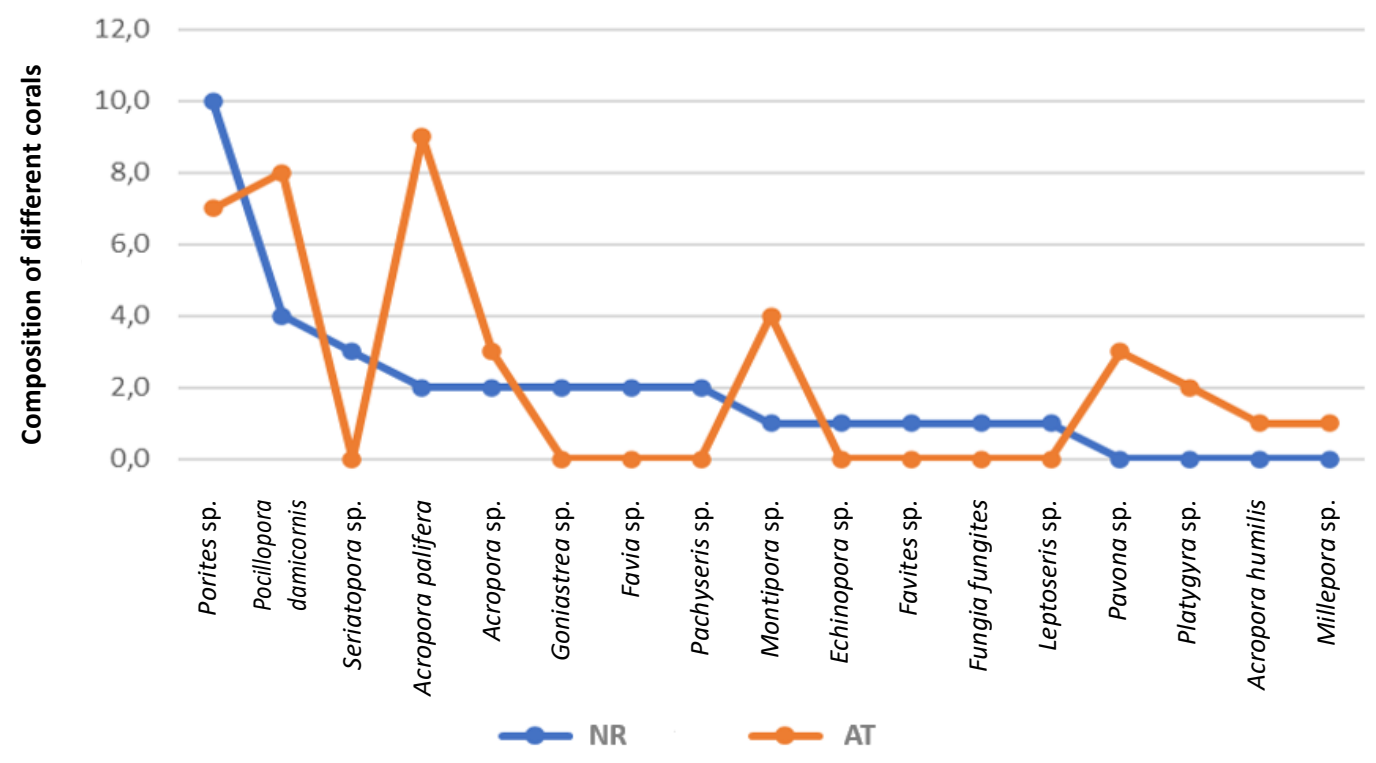

Figure 5. Composition of ratio the number of coral species encountered on bioreeftek between Pemuteran (NR) and Lovina (AT)

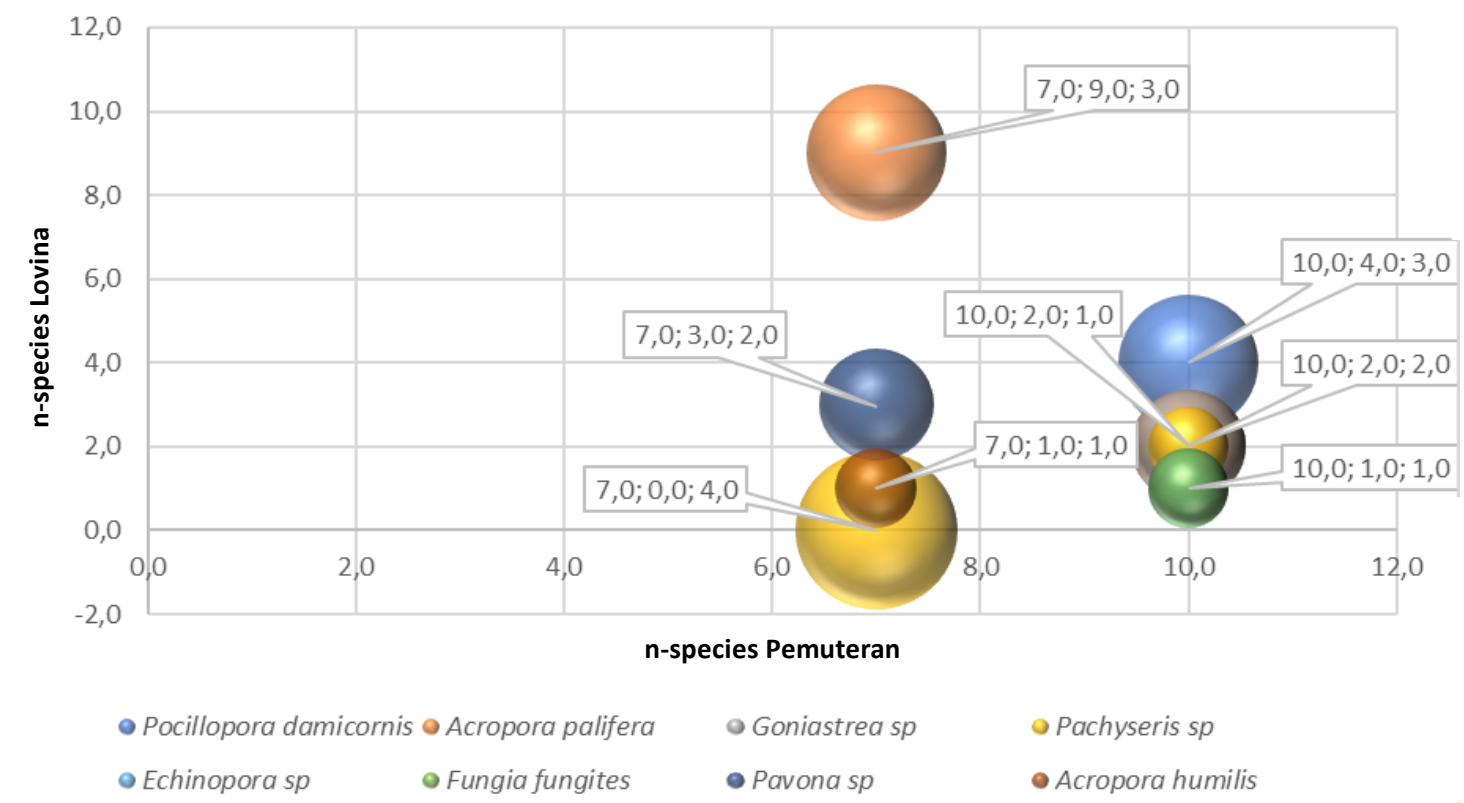

Figure 6. Clustering between types of coral encountered on bioreeftek in Pemuteran (NR) and Lovina (AT) of northern Bali, Indonesia 

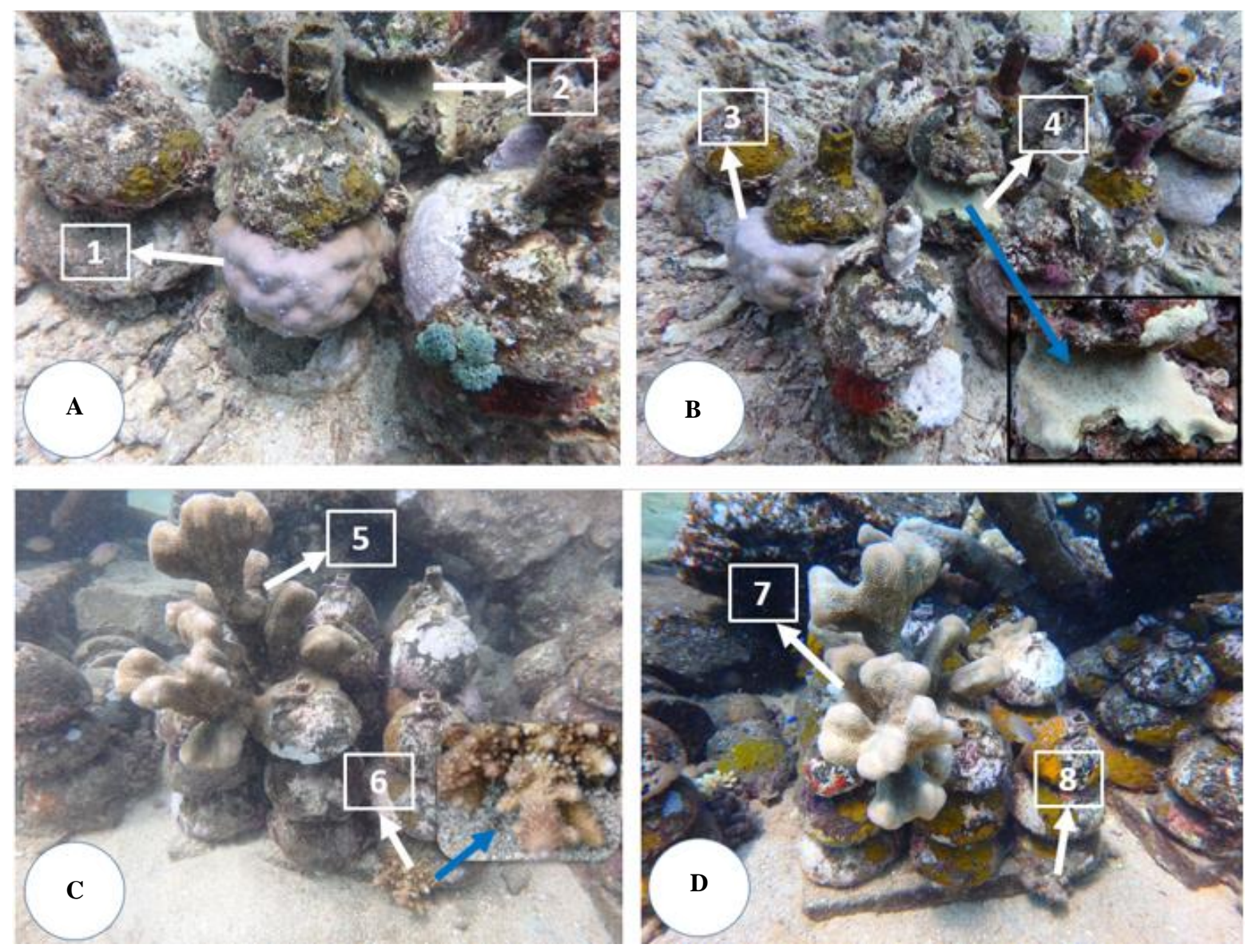

Figure 7. A. Monitoring March 2018 (1. Porites sp.; 2. Montipora sp.); B. Monitoring September 2018 (3. Porites sp.; 4. Montipora sp. with zoom macro-blue arrow) Dive site NR, Pemuteran; C. Monitoring March 2018 (5. Acropora palifera; 6. Acropora humilis with zoom macro-blue arrow); D. Monitoring September 2018 (7. Acropora palifera; 8. Acropora humilis) Dive site AT, Lovina

The distribution patterns of coral species in particularly hard coral (Scleractinian) and community structure at two locations are generally relatively similar because the area is homogeneous as same as in the Komodo Archipelago also in the Lesser Sunda Island chain, Indonesia (Fox 2004; Turak and DeVantier 2012). Corals of the Acropora genus grow fastest and develop on some artificial reefs by transplantation methods (Bongiorni et al. 2011; Munasik et al. 2020). Likewise, on artificial reefs biorock there were deployed in the waters of Buleleng which dominate by Acropora branching (Arifin et al. 2017) and same as in bioreeftek in NR, Pemuteran and AT, Lovina which is dominated by the genus Porites, Pocillopora dan Acropora. The addition of new recruitments of coral is growing fast. The extent of cover to the structure is higher if the reef fracture is inserted. In fact, in some structures, the insertion is done with dead coral. The resulting cover is the same as the insertion with live coral reefs. This is an important note that the placement of artificial reef structure on coral reefs will accelerate the closure of these structures. The condition of coral reefs, the location of initial placement, will influence coral cover of the bioreeftek structure. Coral recruitment at two sites is different, because the deployment time is different between the two, where NR has entered 10 years, while AT 6 years, which greatly influences the recruitment process of coral planula larvae on artificial reefs, in this case, bioreeftek.

Based on observation inserted method particularly the surviving genus of Acropora, the growth rate of coral cover is relatively fast. A month since it was inserted, Acropora has covered $\pm 70 \%$ in coconut shells bioreeftek, despite before being inserted, the coconut shells have been covered by microalgae and ascidians. This does not apply to inserted with dead coral and overgrown with microalgae. However, the genus of Porites and Pocillopora grow naturally on bioreeftek, so consideration should be given to the placement of new bioreeftek to use the inserted method of dead corals. In addition, it shows the ability to compete with CCA, microalgae and ascidian (Barott et al. 2011; Cleary et al. 2016; Gómez-Lemos et al. 2018).

The main concept of the product is if there is a coral larva attached to the bioreeftek substrate then what should be done is: Placement of bioreeftek must be in areas of coral reefs that are relatively rich in diversity, and it is also possible to do coral propagation by tying coral saplings to the top of bioreeftek aluminum poles; Move all media to areas where coral diversity is relatively lacking, in this case, the coral reef ecosystem and its associations, or it can also move each substrate in this case the coconut shells (removed one by one from the aluminum pole) to be 
tagged/adopted (for tourism, etc.) then peg in the middle hole of the coconut shell with bamboo or other environmentally friendly material; Using the base media with aluminum substrates and it can be reused with new coconut shells; Last but not least the process relocation must be determined and discuss in advance related to appropriateness area where to deploy. Ideally, monitoring should be carried out by periodic observation (English et al. 1997; Bianchi et al. 2004; Ampou et al. 2019), every 3 or 6 months, more often is better. The next step by camera and video to document the growth and development of planula larvae that attach to the bioreeftek substrate over time.

As an ecosystem that is very vulnerable and as an indicator to see the level of health, it is necessary to arrange sustainable ecosystem for future management actions (Hill and Wilkinson 2004; Lazuardi et al. 2012; Dee et al. 2014), such as reef rehabilitation. The concept of coral reef rehabilitation is very necessary, especially in ecosystems damaged by natural factors or human activities such as dynamite fishing, blast fishing, etc., and also studies related to the pattern of ocean currents are needed in looking at the distribution of coral planula larvae attached to artificial reefs (Fox 2004). An innovative ecological engineering strategy is needed in minimizing damage to coral reef ecosystems (Burt et al. 2011; Firth et al. 2016; Heery et al. 2018). So, this research suggests using natural materials to built artificial reefs such as coconut shells in addressing the degradation of coral reef ecosystems due to climate change, human activities, etc., also to minimize sea pollution and environmentally friendly. The more value of this bioreeftek structure with other artificial reefs besides natural product, natural recruitment, and propagation/transplants is the insertion/inserted method (Figure 7.C5; Figure 7.D7).

\section{ACKNOWLEDGEMENTS}

This study was supported by DIPA funding BROLKKP, 2018. We thank local staff of Reefseen divers resort, Pemuteran; True Scuba dive center and Pokmaswas Penimbangan Lestari, Buleleng for field assistance. The paper benefited from discussion with Stuart Campbell and Phillip Dustan for constructive comments to improve our manuscript. We also thank Munasik and anonymous reviewers for their useful suggestions.

\section{REFERENCES}

Allen GR, Steene R. 1994. Indo-Pacific Coral Reef Field Guide. Tropical Reef Research, USA.

Ampou EE. 2012. Suatu Struktur untuk Pembudidayaan Terumbu Karang No. Paten S0001231 B. Kementerian Hukum dan Hak Asasi Manusia. Sentra Kekayaan Intelektual, Kementerian Kelautan dan Perikanan, Indonesia. [Indonesia]

Ampou EE. 2016. Caractérisation de La Résilience Des Communautés Benthiques Récifales Par Analyse d'images à Très Haute Résolution Multi-Sources: Le Cas Du Parc National de Bunaken, Indonésie. Université Toulouse III, Paul Sabatier, France. http://thesesups.upstlse.fr/3412/. [France]

Ampou EE, Ouillon S, Andréfouët S. 2018. Challenges in rendering coral triangle habitat richness in remotely sensed habitat maps: The case of
Bunaken Island (Indonesia). Mar Pollut Bull 131: 72-82. DOI: 10.1016/j.marpolbul.2017.10.026

Ampou EE, Hutasoit P, Janetski N, Yusuf S, Damar A, Petta C, Hutahaean AA. 2019. Implementation of coral propagation for coral reef garden in Nusa Dua, Bali. IOP Conf Ser Earth Environ Sci 370: 012080. DOI: $10.1088 / 1755-1315 / 370 / 1 / 012080$

Ampou EE, Triyulianti I, Widagti N, Nugroho SC, Pancawati Y. 2020. Bacteria on Scleractinia reefs in Bunaken, Morotai and Raja Ampat Waters. Jurnal Pesisir dan Laut Tropis 8 (1): 122-134. [Indonesian]

Ampou EE, Widagti N. 2018. Bioreeftek, Panduan Teknis. Bali Riset dan Observasi laut, Jembrana, Bali. [Indonesia]

Andréfouët S. 2008. Coral reef habitat mapping using remote sensing: A user vs producer perspective. implications for research, management and capacity building. J Spat Sci 53: 113-129. DOI: 10.1080/14498596.2008.9635140

Andayani A, Ampou EE. 2018. Pemanfaatan Bioreeftek Sebagai Alternatif Terumbu Buatan di Kabupaten Buleleng, Bali. In Rehabilitasi Ekosistem Terumbu Karang Untuk Keberlanjutan Sumberdaya Perikanan, 1st ed. Amafrad Press \& Badan Riset dan Sumberdaya Manusia Kelautan dan Perikanan, Jakarta. [Indonesian]

Arifin F, Dirgayusa IGNP, Faiqoh E. 2017. The structure of fish and coral cover communities in the Biorock Area of Pemuteran Village, Buleleng, Bali. J Mar Aquat Sci 3: 59. DOI: 10.24843/jmas.2017.v3.i01.59-69. [Indonesian]

Asaad I, Lundquist CJ, Erdmann MV, Costello MJ. 2018. Delineating priority areas for marine biodiversity conservation in the Coral Triangle. Biol Conserv 222: 198-211. DOI: 10.1016/j.biocon.2018.03.037

Barton JA, Willis BL, Hutson KS. 2017. Coral propagation: A review of techniques for ornamental trade and reef restoration. Rev Aquac 9: 238-256. DOI: 10.1111/raq.12135

Barott KL, Rodriguez-Brito B, Janouškovec J, Marhaver KL, Smith JE, Keeling P, Rohwer FL. 2011. Microbial diversity associated with four functional groups of benthic reef algae and the reef-building coral Montastraea annularis: Microbial diversity on benthic algae and corals. Environ Microbiol 13 (5): 1192-1204. DOI: 10.1111/j.14622920.2010.02419.x

Bianchi CN, Pronzato R, Cattaneo-Vietti R, Cecchi LB, Morri C, Pansini M, Chemello R, Milazzo M, Fraschetti S, Terlizzi A, Peirano A, Salvati E, Benzoni F, Calcinai B, Cerrano C, Bavestrello G. 2004. Hard Bottoms. Biol Mar Medit 11: 185-215.

Bluman AG. 2012. Elementary Statistics: A Step by Step Approach, Eight Edition. ed. Mc Graw Hill, New York.

Bongiorni L, Giovanelli D, Rinkevich B, Pusceddu A, Chou LM, Danovaro R. 2011. First step in the restoration of a highly degraded coral reef (Singapore) by in situ coral intensive farming. Aquac 322323: 191-200. DOI: 10.1016/j.aquaculture.2011.09.024

Burt J, Bartholomew A, Bauman A, Saif A, Sale PF. 2009. Coral recruitment and early benthic community development on several materials used in the construction of artificial reefs and breakwaters. $\mathbf{J}$ Exp Mar Biol Ecol 373 (1): 72-78. DOI: 10.1016/j.jembe.2009.03.009

Burt J, Bartholomew A, Sale PF. 2011. Benthic development on largescale engineered reefs: A comparison of communities among breakwaters of different age and natural reefs. Ecol Eng 37 (2): 191198. DOI: 10.1016/j.ecoleng.2010.09.004

Cleary DFR, Polónia ARM, Renema W, Hoeksema, BW, RachelloDolmen, Moolenbeek RG, Budiyanto A, Yahmantoro, Tuti Y, Giyantof, Draismag SGA, van Reine WFP, Hariyanto R, Gittenberger RA, Rikoh MF, de Voogd NJ. 2016. Variation in the composition of corals, fishes, sponges, echinoderms, ascidians, molluscs, foraminifera and macroalgae across a pronounced in-to-offshore environmental gradient in the Jakarta Bay-Thousand Islands coral reef complex. Mar Pollut Bull 110 (2): 701-717. DOI: 10.1016/j.marpolbul.2016.04.042

Cruz-Trinidad A, Aliño PM, Geronimo RC, Cabral RB. 2014. Linking food security with coral reefs and fisheries in the coral triangle. Coast Manag 42 (2): 160-182. DOI: 10.1080/08920753.2014.877761

Dahl AL. 1981. Coral Reef Monitoring Handbook. South Pacific Commission Noumea, New Caledonia

Dee LE, Horii SS, Thornhill DJ. 2014. Conservation and management of ornamental coral reef wildlife: Successes, shortcomings, and future directions. Biol Conserv 169: 225-237. DOI: 10.1016/j.biocon.2013.11.025

Douglas AE. 2003. Review: Coral bleaching-how and why? Mar Pollut Bull 46 (4): 385-392. DOI: 10.1016/S0025-326X(03)00037-7 
Dunn JC. 1974. Well-separated clusters and optimal fuzzy partitions. J Cybern 4: 95-104. DOI: 10.1080/01969727408546059

Putra RD, Suryanti A, Kurniawan D, Pratomo A, Irawan H, Raja TS, Kurniawan R, Pratama G, Jumsuriza. 2018. Responses of herbivorous fishes on coral reef cover in outer island Indonesia (Study case: Natuna Island). E3S Web Conf 47: 04009. DOI: 10.1051/e3sconf/20184704009

English S, Wilkinson C, Baker V. 1997. Survey Manual for Tropical Marine Resources, 2nd edition., ASEAN. ed. Australia Marine Science Project, Living Coastal Resources, Australian Institute of Marine Science, Townsville, Australia.

Geospatial Information Agency, The Center for Naval Hydrography and Oceanography, Coordinating Ministry for Maritime Affairs. 2018. National Reference of Indonesian Territorial Data. [Indonesian]

Ferse SCA, Nugues MM, Romatzki SBC, Kunzmann A. 2013. Examining the use of mass transplantation of brooding and spawning corals to support natural coral recruitment in Sulawesi/Indonesia: Effects of coral transplantation on coral recruitment. Restor Ecol 21: 745-754. DOI: $10.1111 /$ rec. 12004 .

Firth LB, White FJ, Schofield M, Hanley ME, Burrows MT, Thompson RC, Skov MW, Evans AJ, Moore PJ, Hawkins SJ. 2016. Facing the future: the importance of substratum features for ecological engineering of artificial habitats in the rocky intertidal. Mar Freshw Res 67 (1): 131-143. DOI: 10.1071/MF14163.

Foale S, Adhuri D, Aliño P, Allison EH, NeilAndrew N, Cohen P, Evans L, Fabinyi M, Fidelman P, Gregory C, Stacey N, Tanzer JT, Weeratunge N. 2013. Food security and the coral triangle initiative. Mar Policy 38: 174-183. DOI: 10.1016/j.marpol.2012.05.033.

Fox HE. 2004. Coral recruitment in blasted and unblasted sites in Indonesia: Assessing rehabilitation potential. Mar Ecol Prog Ser 269: 131-139. DOI: 10.3354/meps269131.

Fox HE, Mous PJ, Pet JS, Muljadi AH, Caldwell RL. 2005. Experimental assessment of coral reef rehabilitation following blast fishing. Conserv Biol 19: 98-107. DOI: 10.1111/j.1523-1739.2005.00261.x

Gómez-Lemos LA, Doropoulos C, Bayraktarov E, Diaz-Pulido G. 2018 Coralline algal metabolites induce settlement and mediate the inductive effect of epiphytic microbes on coral larvae. Sci Rep 8: 17557. DOI: 10.1038/s41598-018-35206-9.

Goreau TJ. 2009. Coral Reef and Fisheries Habitat Restoration in the Coral Triangle: The Key to Sustainable Reef Management. Proceeding of Coral Reef Management Symposium on Coral Triangle Area. Presented at the Coral Reefs Management Symposium on Coral Triangle Area, COREMAP II, Directorate General of Marine, Coasts and Small Islands Ministry of Marine Affairs and Fisheries, Jakarta, Indonesia.

Grimsditch GD, Salm RV. 2006. Coral Reef Resilience and Resistance to Bleaching. IUCN Gland, Switzerland.

Heery EC, Hoeksema BW, Browne NK, Reimer JD, Ang PO, Huang D, Friess DA, Chou LM, Loke LHL, Saksena-Taylor P, Alsagoff N, Yeemin T, Sutthacheep M, Vo SI, Bos AR, Gumanao GS, Hussein MAS, Waheed Z, Lane DJW, Johan O, Kunzmann A, Jompa J, Suharsono, Taira D, Bauman AG, Todd PA. 2018. Urban coral reefs: Degradation and resilience of hard coral assemblages in coastal cities of East and Southeast Asia. Mar Pollut Bull 135: 654-681. DOI: 10.1016/j.marpolbul.2018.07.041

Hill J, Wilkinson C. 2004. Methods for Ecological Monitoring of Coral Reefs. Australian Institute of Marine Science, Townsville, Australia.

Hoegh-Guldberg O. 1999. Climate change, coral bleaching and the future of the world's coral reefs. Mar Freshw Res 50: 839-866. DOI: 10.1071/MF99078

Larson R, Farber B. 2012. Elementary Statistic: Picturing the World, Fifth Edition. Pearson Education, Boston.

Lazuardi ME, Sudiarta IK, Ratha IMJ, Ampou EE, Nugroho SC, Mustika PL. 2012. Chapter 4: The Status of Coral Reefs in Bali. Bali Marine
Rapid Assessment Program 2011, RAP Bulletin Biological Assessment of 64. Conservation International All rights reserved, Denpasar, Bali, Indonesia.

Munasik M, Sabdono A, Assyfa AN, Wijayanti DP, Sugiyanto S, Irwani I, Pribadi R. 2020. Coral transplantation on a multilevel substrate of artificial patch reefs: Effect of fixing methods on the growth rate of two Acropora species. Biodiversitas 21 (5): 1816-1822. DOI: 10.13057/biodiv/d210507

Nañola CL, Aliño PM, Carpenter KE. 2011. Exploitation-related reef fish species richness depletion in the epicenter of marine biodiversity. Environ Biol Fishes 90: 405-420. DOI: 10.1007/s10641-010-9750-6

Plass-Johnson JG, Cardini U, van Hoytema N, Bayraktarov E, Burghardt I, Naumann MS, Wild C. 2015. Coral bleaching. In: Armon RH, Hänninen O (eds.). Environmental Indicators. Springer, Dordrecht, Netherlands.

Putra MD, Bláha M, Wardiatno Y, Krisanti M, Yonvitner, Jerikho R, Kamal MM, Mojžišová M, Bystřický PK, Kouba A, Kalous L, Petrusek A. Patoka J. 2018. Procambarus clarkii (Girard, 1852) and crayfish plague as new threats for biodiversity in Indonesia. Aquat Conserv Mar Freshw Ecosyst 28: 1434-1440. DOI: 10.1002/aqc.2970

Raymundo LJ, Couch CS, Harvell CD. 2008. Coral Disease Handbook: Guidelines for Assessment, Monitoring \& Management. Coral Reef Targeted Research and Capacity Building for Management Program, Centre for Marine Studies, University of Queensland, St. Lucia, Qld.

Saha S, Bandyopadhyay S. 2012. Some connectivity based cluster validity indices. Appl Soft Comput 12: 1555-1565. DOI: 10.1016/j.asoc.2011.12.013

Scopélitis J, Andréfouët S, Phinn S, Done T, Chabanet P. 2011. Coral colonisation of a shallow reef flat in response to rising sea level: Quantification from 35 years of remote sensing data at Heron Island, Australia. Coral Reefs 30: 951-965

Tito CK, Ampou EE, Wibawa TA. 2019. Stressor-response of reefbuilding corals to climate change in the Menjangan Island, West Bali National Park, Indonesia. IOP Conf Ser Earth Environ Sci 246: 012011. DOI: 10.1088/1755-1315/246/1/012011.

Trialfhianty TI, Suadi. 2017. The role of the community in supporting coral reef restoration in Pemuteran, Bali, Indonesia. J Coast Conserv 21: 873-882. DOI: 10.1007/s11852-017-0553-1.

Tomascik T, Clarke AJ, Nontji A, Moosa MK. 1997. The Ecology of Indonesian Seas, Part I. The Ecology of Indonesia Series, Volume VII. Periplus, Singapore.

Turak E, DeVantier L. 2012. Chapter 5: Biodiversity and Conservation Priorities of Reef-building Corals in Bali, Indonesia. Bali Marine Rapid Assessment Program 2011, RAP Bulletin Biological Assessment of 64. Conservation International, Denpasar, Bali, Indonesia.

Turak E, DeVantier L. 2003. Reef-Building Corals of Bunaken National Park, North Sulawesi, Indonesia: Rapid Ecological Assessment of Biodiversity and Status. Final Report to the International Ocean Institute Regional Centre for Australia \& the Western Pacific, Australia.

Veron JEN, DeVantier LM, Turak E, Green AL, Kininmonth S, StaffordSmith M, Peterson N. 2009. Delineating the coral triangle. Galaxea J Coral Reef Stud 11: 91-100.

Williams SL, Sur C, Janetski N, Hollarsmith JA, Rapi S, Barron L, Heatwole SJ, Yusuf AM, Yusuf S, Jompa J, Mars F. 2019. Largescale coral reef rehabilitation after blast fishing in Indonesia: Coral reef rehabilitation. Restor Ecol 27: 447-456. DOI: 10.1111/rec.12866

Yunaldi, Arthana IW, Astarini IA. 2011. Study of the development of coral fish community structure on artificial reefs in the form of hexadome in various waters conditions in Buleleng Regency, Bali. Jurnal Ilmu Lingkungan 6: 107-112. [Indonesian] 